\title{
An Evaluation of Holistic Integrative Early Childhood Education
} in Indonesia

\author{
Heni Damaiyanti \\ LKP Hastari, Indonesia \\ e-mail: henydamaiyanti72@gmail.com \\ Edi Harapan \\ Universitas PGRI Palembang, Indonesia \\ e-mail: ehara205@gmail.com \\ Yenny Puspita \\ Universitas PGRI Palembang, Indonesia \\ e-mail: yenny_puspitaa@yahoo.com
}

Article History: Received on 15 July 2020, Revised on 20 July 2020, Published on 27 July 2020

\begin{abstract}
This study evaluated the integrative holistic early childhood education at Ananda Palembang Kindergarten. The evaluation model used in this study is the CIPP Model. The data analysis technique used was qualitative approach. Data were collected through interviews, observation and documentation study. The results showed that 1) context evaluation states that there is no strong legal foundation in the integrative holistic early childhood development program in Ananda Palembang Kindergarten; 2) input evaluation states that Ananda Palembang Kindergarten has been running existing services in holistic integrative early childhood education by having adequate resources; 3 ) process evaluation states that Ananda Palembang Kindergarten in education, health and nutrition, nursing, care services, protection services and welfare services has been implemented in this institution; 4) product evaluation states that Ananda Kindergarten has been proven by being accredited A in 2018. This paper contributes to other Kindergarten in Indonesia where they will have good accreditation could see Ananda Palembang Kindergarten.
\end{abstract}

Keywords: Holistic Integrative; Early Childhood Education; Evaluation

\section{A. Introduction}

Early childhood education is one form of education that focuses on laying the foundation towards the growth and development of motor coordination, emotional intelligence, plural intelligence and spiritual intelligence. Education is the right that must be received by a child as stipulated in Law Number 23 of 2003 Article 9 paragraph 1 regarding child protection "Every child has the right to receive education and teaching in the context of personal development and the level of intelligence according to his interests and talents". And the National Education System Law Number 20 Year 2003 chapter 1 item 14 (Sudjana, 2010: 306) states that early childhood education is a coaching effort aimed at children from birth until the age of six carried out through the provision of educational stimuli to help physical and spiritual growth and development so that children have readiness to enter further education. 
In Presidential Regulation No. 60 of 2013 concerning Integrative Holistic Early Childhood Development explained that Integrative Holistic Early Childhood Development is an early childhood development effort undertaken to meet the essential needs of diverse and interrelated children simultaneously, systematically, and integrated holistic stimulation services including 1) services education, 2) health, 3) nutrition, 4) care, 5) care, 6) protection, and 7) welfare becomes a policy of early childhood development by involving relevant parties both government agencies, social organizations, professional organizations, community leaders and people parents (Kindergarten Development Director, 2015).

The quality of human resources has now become the main indicator in measuring and describing the progress of a nation; on this basis each country has placed human resource development as the main program and development strategy issue, including the State of Indonesia. This proves that there have been many studies related to early childhood showing that, the preparation of quality resources must begin early, even from the time of conception in the womb. The fulfillment of fulfilling the development and growth needs of children in an integrated holistic manner will determine the quality of health, intelligence, and social maturity in the next stage.

In the Early Childhood Education program, parents and teachers can work together in guiding children to become a great generation. However, the implementation of Kindergarten still faces various problems, so the concept of Kindergarten begins to shift. Experts also recommend the need to develop holistically and integrated early childhood.

The Government's considerations and foundation for carrying out Holistic Early Childhood Education include, among others a) healthy, intelligent, and productive human resources are valuable assets for the nation and the State of Indonesia; b) an increase in the quality of human resources in achieving optimal growth and development is largely determined by the quality of child development during the early age period, namely from the fetus to the 6-year-old child, which can be seen from the increased degree of health and nutritional status, intelligence and cheerfulness, emotional maturation and spiritual, and child welfare; c) in order to guarantee the fulfillment of the right to growth and development of early childhood, efforts are needed to improve, health, nutrition, care, care, protection, welfare, and educational stimuli carried out simultaneously, systematically, thoroughly, integrated, and continuously (Presidential Regulation No. 60 of 2013).

This consideration clearly states that meeting all aspects of the needs of early childhood is an important factor in efforts to improve the quality of human resources in Indonesia. Some aspects that determine human quality and need to be fostered early on are health, nutrition, and intellectual and emotional stimulation of children. These three things need to be handled simultaneously and synergy from an early age. In fact, for health and nutrition must be started in the womb. Therefore, starting a new training at the age of kindergarten is considered too late (Raharjo, 2006), where the development of children's intelligence reaches 50\% at the age of 0-4 years, $80 \%$ at the age of 4-8 years, and $100 \%$ at the age of 8-18 years. While the physical growth of children aged o years reached $25 \%, 6$ years reached $90 \%$, and 12 years reached $100 \%$ (Osbon, White, and Bloom, 2004), and 50\% of cognitive abilities formed at the age of 0-4 years. Therefore, intervention, social, and personality of a person in further development (Siswanto, 2014: 137). 
Thus, early childhood education cannot be carried out on its own with only one aspect taught but requires a combination of several aspects of integrated children's needs so that children can grow and develop into children who are healthy, intelligent, cheerful and noble. In this way the aim of Kindergarten is to form quality children, children who grow and develop according to their level of development so that they have optimal readiness in entering basic education and wading through life in adulthood (Tedjawati, 2011: 123) will be achieved to the maximum if the essential needs of children early age are not fulfilled. The above opinion is supported by research conducted by Diana, Symon \& Yurizal, (2011: 10) which states that the lower the nutritional status of children, the higher the development delay. Furthermore, the study by Husnaini (2003) suggested that poor nutritional status tended to be grosser in motor development $(25 \%)$ and 8 times more likely to be delayed in gross motor development than children with normal nutritional status and $90 \%$ of brain growth occurred in two first year of his life and very dependent on the nutrition he gets.

Increased social behavior tends to be most conspicuous in early childhood. This is caused by increasing social experience and children learn the views of others, towards their behavior and how these views affect the level of acceptance from peer groups (Hurlock, 2012).

From the description of the child's behavior patterns according to Hurlock, it is concluded that early childhood is a very important period to be able to determine the social development of children in the future so it is very important to pay attention. Especially in social development so that children can develop into children who can adapt to the environment and society because in early childhood the improvement of social behavior is very important and determines how the pattern of children's social behavior in the next stage.

From the above statement, it can be stated that the Implementation of Integrative Holistic Early Childhood Development is important to be implemented. Especially when seen in general that most parents realize the importance and benefits of Kindergarten for children. However, there is a strong perception that Kindergarten is only a place to prepare for entering primary school (reading, writing and arithmetic skills) rather than holistic child development (Bapenas, 2013). School readiness should be included in a child's holistic development, which includes verbal and intellectual skills and knowledge, social abilities, and health and nutrition status. From the results of a study conducted by UNICEF (2012), showing that poor educational performance, decreased length of education, and decreased income as adults, all of them can be attributed to young people who are short in stature. For this reason, children will benefit the most if Kindergarten programs are holistic in nature that integrates psychosocial interventions and school readiness with health and nutrition interventions (UNICEF, 2012).

This condition can indicate that there is Early Childhood Education that has not been carried out to the maximum. This indication is then supported by the findings of researchers that there is no clear and integrative line of communication between the Palembang City Early Childhood Education Unit and agencies related to the implementation of Integrative Holistic Early Childhood Development services. Thus, the researcher considers that it is necessary to evaluate the Integrative Holistic Early Childhood Education at Ananda Kindergarten Palembang.

\section{B. Methods}

The research method in this research is descriptive qualitative method. Qualitative research methods According to Sugiyono (2012: 15) is a research method based on the philosophy of 
post positivism which is used to examine the conditions of natural objects. While Moleong (2016: 6) qualitative research is research that intends to understand the phenomena about what is experienced by integrative holistic research subjects, and by means of descriptions in the form of words and languages, in a special natural context and by utilizing various methods scientific.

The use of descriptive qualitative methods for several reasons 1) qualitative methods are easier when dealing with multiple realities, this method presents a direct relationship between researchers and respondents; and 2) qualitative research methods where the data collected in the form of words and images, the data collected can be the key to what has been studied; 3 ) he problems in qualitative research are unclear, holistic, dynamic and full of meaning, also this method is useful in helping to solve problems that arise, and can be used to produce a situation that might be present in the situation. Qualitative descriptive methods are very helpful to find out how to achieve the desired goals, moreover qualitative descriptive research is more widely used in the field of inquiry with the reason it can be applied to various kinds of problems. Then the research report will be in the form of data quotations to illustrate the report's presenters, while all data is generated from interviews, and documentation.

Research instruments in qualitative research methods are the researchers themselves, therefore researchers as instruments must be validated (Sugiyono, 2012: 305). Whereas Arikunto (2010: 27) in qualitative research is known as audit trail, audit means checking and trail means small road. So the qualitative audit trail research is to do an analysis or trace back all the files collected from a series of research activities, and these searches are carried out together in the form of peer-to-peer discussions.

Sugiyono (2012: 306) states that the research instrument in qualitative research, there is no other choice than to make humans as the main research instrument. Because of that, things do not yet have a definite form.

The research instrument was distributed to the principal, five teachers, three parents/guardians of students in order to obtain the necessary data relating to the research being carried out. In order to maintain the confidentiality of the data taken, the researcher disguises the name of the informant whose information is requested so that the data is more accurate and the informant has no difficulty in providing the actual information, and to maintain the privacy of the subject under study, also disguised the name of the subject under study.

\section{Results and Discussion}

Context Evaluation in this research aims to find out whether Integrative Holistic Early Childhood Education Kindergarten in Palembang has a strong formal foundation and whether Integrative Holistic Early Childhood Education is needed by the Kindergarten Palembang. In other words, whether the program is a program that is considered responsive to the problems that exist in the Kindergarten Palembang, especially in Ananda Kindergarten Palembang Presidential Regulation No. 60 of 2013 is a strong legal basis, as long as there is no substitute Presidential Regulation to revise the Presidential Regulation, then Presidential Regulation No. 60 of 2013 remains in force and must continue to be implemented. 
Because of the technical Integrative Holistic Early Childhood Education in Kindergarten has not been regulated in detail in Presidential Regulation No. 60 of 2013, therefore the Palembang City Government must have a Regional Regulation that regulates the Integrative Holistic Early Childhood Education in the Kindergarten in particular the coordination between each agency related to the delivery of program services.

Generally, the expectations of Parents of Students to Kindergarten are as a place to learn to read, count, and write. That $66 \%$ of the parents 'goals are that they send their children to Kindergarten so that their children are good at reading, writing and counting, and $16 \%$ of the parents' goals are for their children to have independence, then 5\% want their children to be able to adapt, and $13 \%$ expect their children can have positive character.

That $53 \%$ of parents want their children to excel in academics after studying at Ananda Kindergarten Palembang and $26 \%$ of parents want their children to quickly adapt to further education after attending Kindergarten in Palembang, then $13 \%$ want their children to have independence and discipline after taking education in Ananda Kindergarten Palembang, and 8\% expect their children to have high self-confidence after studying at Ananda Kindergarten Palembang.

Ananda Palembang Kindergarten is an institution that actually has a basic basis in the implementation of Integrative Holistic Early Childhood Education, even though the integrative element has not been implemented to the maximum. Thus, Integrative Holistic Early Childhood Education is a program that is considered responsive to the problems that exist in Ananda Palembang Kindergarten, the demands of parents or community that Kindergarten as an educational unit must be able to become a means of verbal fulfillment (reading, counting, and writing).

Input evaluation in this study aims to determine the available sources, what alternatives are taken, what are the plans and strategies to achieve needs, and how work procedures to achieve them (Kristiawan et al, 2016). Resources that support the fulfillment of aspects of educational services in Ananda Kindergarten Palembang are professional teachers, school culture that is successful in character culture, facilities and infrastructure, curriculum for learning developed by schools. Teachers who teach are in accordance with the field of Early Childhood Education. School culture which succeeded in character education by way of queuing when children wash hands before and after eating, is responsible for arranging shoe bags, toys that have been used to be tidied up and returned back to their places, children are taught to speak in words be wise in a positive, positive attitude, confident, independent, polite, humble and honest. Very adequate, varied, safe, comfortable, beautiful, attractive and neatly arranged facilities and infrastructure according to the needs and standards of Early Childhood Education. The curriculum and learning are developed based on the Curriculum 2013 of Early Childhood Education.

In this process evaluation, the researcher conducts an evaluation with a qualitative descriptive approach, in which the researcher finds that the implementation of Integrative Holistic Early Childhood Education was very good. For product evaluation, Ananda Palembang Kindergarten is very helpful for parents to know how parents should provide nutritious food for children, and its limits. In addition to fulfilling nutrition for children, this knowledge can prevent obesity for children. 
The results of the research presented above are supported by some of the earliest studies, the results of research from Klam (2014) explaining that the process of implementing non-formal education program policies in early childhood education in Sintang sub-district has not gone well, due to the lack of government support in the implementation of early childhood education, foundation or organization, there is still no synergy between the government, Early Childhood Education management institutions and the community to conduct joint supervision and control. Early Childhood Education development involves the government, private sector and the community. For communication to run smoothly there should be a coordinating agency for all Early Childhood Education development. In order for the process of implementing non formal Early Childhood Education policies to run smoothly, the community is expected to also be involved in assessment control and in making decisions on the implementation of Early Childhood Education policy.

The results of research conducted by Darman (2017) with the results that explain that to prepare the golden generation of Indonesia in 2045 is important for the world of education to change the mindset. Education is not just meant by academic transfer, but it is equipped with character. It is this academic and character balance that needs to be prepared from now on. To reach the golden generation of Indonesia, efforts are also needed to improve the quality of education in Indonesia such as 1) Increase the education budget, 2) management of education management, 3) freeing schools from the business atmosphere, 4) improving curriculum, 5) religious education, 6) training education critical awareness, 7) teacher empowerment.

\section{Conclusion}

Integrative Holistic Early Childhood Education at Ananda Palembang Kindergarten already has a strong legal foundation. Ananda Palembang Kindergarten has sufficient resources to provide Holistic Early Childhood Education services. The process of implementing Integrative Holistic Early Childhood Education services at Ananda Palembang Kindergarten has been running quite well and in accordance with the techniques for providing Holistic Early Childhood Education services. Product Results Evaluation of Integrative Holistic Early Childhood Education in Ananda Palembang Kindergarten has been carried out in accordance with the level of development and growth of children with the aim of producing quality children, children who grow and develop according to their level of development so as to have optimal readiness in entering basic education and wade through life in adulthood.

\section{E. Acknowledgement}

We would like to express our special thanks and gratitude to Rector Universitas PGRI Palembang who gave us the support to do this wonderful project. This project was funded independent. Secondly, we would also like to thank our friends in management of education Universitas PGRI Palembang who helped us a lot in finalizing this project within the limited time frame.

\section{REFERENCE}

Arikunto, S. (2010). Evaluasi Program pendidikan [Educational Program Evaluation]. Jakarta: Rhineka Cipta.

Bappenas, (2013). Studi Strategi Pengembangan Anak Usia Dini di Indonesia [Study on Early Childhood Development Strategies in Indonesia]. Jakarta: Bappenas. 
Darman, R. A. (2017). Mempersiapkan Generasi Emas Indonesia tahun 2045 Melalui Pendidikan Berkualitas [Preparing the Indonesian Golden Generation in 2045 through Quality Education]. Jurnal Edik Informatika Vol. 3, Page: 73-87.

Diana, M. F, Symon, D, \& Yurizal. (2011). Perbendaan Tumbuh Kembang Anak Pada Posyandu Yang Terintegrasi PAUD Dengan Yang Tidak Trintegrasi PAUD [The Difference of Child Growth in Integrated Health Post integrated with Early Childhood Education and Non- Early Childhood Education Integrated]. Jurnal Kesehatan Masyarakat, 6(1): 10-15.

Kindergarten Development Director. (2015). Petunjuk Teknis Penyelenggaraan Pengembangan Anak Usia Dini Holistik Integratif Di Satuan PAUD [Technical Guidelines for the Implementation of Integrative Holistic Early Childhood Development in Early Childhood Education Unit]. Jakarta: Kemendikbud.

Husnaini, Y. (2003). Rehabilitasi Dan Fleksibilitas Penggunaan Kms Perkembangan Motoric Kasar [Rehabilitation and Flexibility in the Use of Kms Motoric Rough Development].

Hurlock, E. B. (2012). Psikologi Perkembangan, Suatu Pendekatan Sepanjang Rentang Kehidupan [Developmental Psychology, An Approach Throughout the Range of Life]. Jakarta: Erlangga.

Klam. (2014). Implementasi Kebijakan Program Pendidikan Non Formal Pada Pendidikan Anak Usia Dini Di Kecamatan Sintang [Policy Implementation of Non-Formal Education Programs in Early Childhood Education]. Jurnal Administrasi Publik dan Birokrasi Vol. 1 No. 1: 1-9.

Kristiawan, M., Jumeldi, A., Ahmad, S \& Asvio, N. (2016). The Implementation of Affective Assessment for Islamic Education In Hight School 1 Pariangan. Journal Of Social Sciences, 9 (4):1-8.

Law Number 23 of 2003

Moleong, L. J. (2016). Metodologi Penelitian Kualitatif [Qualitative Research Methodology]. Bandung: PT. Remaja Rosdakarya.

Siswanto, H. (2014). Permasalahan Pendidikan Dasar dan Pendidikan Anak Usia Dini [Problems with Basic Education and Early Childhood Education]. Cendekia, 8 (2): 137-150.

Presidential Regulation No. 60 of 2013

Sudjana, N. (2010). Dasar-Dasar Proses Belajar Mengajar [Fundamentals of Teaching and Learning Process]. Bandung: Alfabeta

Sugiyono, (2012). Metode Penelitian Kuantitatif, Kualitatatif dan R\&D [Quantitative, Qualitative, and R\&D Research Methods]. Bandung: Alfabeta. 
Journal of Social Work and Science Education

Volume 1 (1) 2020

E-ISSN: 2723-6919

Tedjawati, J. M. (2011). Peran HIMPAUDI Dalam Pengembangan PAUD [The Role of HIMPAUDI in Early Childhood Education Development]. Jurnal Pendidikan dan Kebudayaan. 17 (1): 123-133.

UNICEF. (2012). Indonesia Laporan Tahunan 2012 United For Children [Indonesia Laporan Tahunan 2012 United For Children]. Jakarta: UNICEF 